\title{
The Revival of Shi'Ism in Southeast Asia and Its Responses: Comparative Study on The Opinions of Scholars and Islamic Authorities
}

\author{
Zubaidi Wahyono ${ }^{1}$, Abdul Salam Muhamad Shukri ${ }^{2}$, Dudin Shobaruddin ${ }^{3}$ \\ \{zubaidi@iium.edu.my¹, abdulsalam@iium.edu.my², sadawangi@gmail.com³ \\ International Islamic University Malaysia ${ }^{1,2}$, \\ Shuffah AlQuran Abdullah bin Masud Institute, Natar, Lampung Indonesia ${ }^{3}$
}

\begin{abstract}
Islam in Southeast Asia (SEA) in general and in Malaysia, Indonesia and Brunei in particular, has been dominated by the ideology of Sunnism since it arrived in the region in the 11th century. However, since few decades ago, other theology especially Shi' ism started to grab the followers among the Sunni Muslim society in the region amidst the controversies arisen. This paper studies the influence of Shi'ism among the Sunni Muslims in SEA particularly in Malaysia, Indonesia and Brunei in order to know how Shi'ism spread and its responses from Muslims scholars as well as religious authorities in the region. By employing library research and observation, this research present the current development of Shi'ism in the region and portray the analytical study on the responses and the opinions of Muslim scholars as well as with the prominent figures of the religious authorities in Malaysia, Indonesia and Brunei. Among the important findings of the research is that Shi'ism managed to get footstep in the region after the Iran revolution in $70^{\text {th }}$ through various methods, education mission, socio-cultural relation as well as ideological propagation. However, as a new ideology, Shi'ism has sparked diverse responses and created polemic among the Muslims society especially among the Muslim scholars and the Islamic authorities in the region due its sensitive issue ideologically, economically and politically.
\end{abstract}

Keywords: Shi'ism, Southeast Asia, ideology, Islamic propagation, Religious Authorities

\section{Introduction}


Shi'ism (Shi' ite ideology) especially has a long history in Muslim history ${ }^{1}$ and Southeast Asia (SEA) as well. ${ }^{2}$ It was recorded that Shi 'ism had arrived in Southeast Asia along with the arrival of Islam in it in the 11th century. The fact could be traced back to the Islamic literature of Southeast Asia and the culture of the Muslims in the region, which indicates the presence of Shi 'ism in it. However, Shi' ism could not get a vast response due to the strong influence of Sunni ideology, which penetrated deeply in the life of the Muslims in the region. ${ }^{3}$

Nevertheless, Shi' ism gained momentum after the Iranian revolution in the early 1980 and this situation has attracted many youngsters around the world including in Southeast Asia to learn about Shi'ism. Many students of high institutions have been targeted for the Shi'ite propagation in Indonesia particularly and in the region in general. Since then Shi 'ism has gained acceptance among the Muslims in the region due to its active propagation by individuals supported by the Iranian government. ${ }^{4}$

This article aims at gauging the influence of Shi'ism among Muslims in SEA, particularly in Malaysia and Indonesia and Brunei and to know the emergence of Shi'ism revived and how it could spread among the Muslims in SEA as well as the responses of the Muslim scholars and religious authorities in particular responses to Shi' ism. This study is based on library research and field

\footnotetext{
${ }^{1}$ See for example, al-Nawbakhti, AbË MuÍammad al-×asan b. MËsa, KitÉb FirÉq al-ShÊ'ah, (al-Qahirah: Dar al-Rashad, 1992); al-Ash'ari, AbË al-×asan, MaqÉlat al-IslÉmiyyẾn wa al-ikhtilaf al-muÎllÊn, 2 vols. (Beirut: Maktabah al-‘Aîriyyah, 1990); al-ShahrastÉni, Muslim Sects and Division, trans. A. K. Kazi \& J. G. Flynn, (London: Kegan Paul International, 1984), Arabic al-Milal wa al-Nihal, 3 jilid, (al-Qahirah, n.d.); Mahmud Shahabi, "The Roots of Shi' ism in Early Islamic History,” in Shi' ism Doctrines, Thought and Spirituality, ed. Syed Hossein Nasr, Hamid Dabashi et al, (New York: State University of New York Press, 1988)

${ }^{2}$ Among the studies on Shi 'ism in Southeast Asia include Zulkifli, The Struggle of the Shi 'is in Indonesia, (Canberra: ANU Press, 2013). This book is based on his doctoral thesis entitled, The Struggle of the Shi' is in Indonesia, Doctoral thesis, Department of Islamic Studies, Faculty of Humanities, Leiden University, 2009

https://openaccess.leidenuniv.nl/handle/1887/14017; Wan Zahidi bin Wan Teh \& Mahmood Sa'ad Nasih, Mengenal Hakikat Syiah, (Kuala Lumpur: Pejabat Mufti Wilayah Persekutuan, 2013); Pejabat Mufti Wilayah Persekutuan, Membendung Pengaruh Syiah, (Kuala Lumpur: Pejabat Mufti Wilayah Persekutuan, 2011); Muhammad Asri Yusoff, Ibn Ishaq: Peranannya dalam Penyebaran Fahaman Syiah di kalangan Ummah, (Kota Bharu: Pustaka Bisyarah, 2004); Muhammad Asri Yusoff, Syiah Rafidah: Di Antara Kecuaian Ulama' dan Kebingungan Ummah, (Kota Bharu: Pustaka Bisyarah, 2010); Wan Mohd Azam Mohd Amin, "The Development of the Concept of Mahdism in the Malay Sunni World," Journal of Islam in Asia (2007), 4 (1): 123-144; Wan Mohd Azam Mohd Amin, Ajaran Sesat, (Kuala Lumpur: IIUM Press, 2001); JAKIM, Penjelasan terhadap Fahaman Syiah, (Kuala Lumpur: Jabatan Kemajuan Islam Malaysia, 1997); Wan Zailan Kamarudin bin Wan Ali, “Aliran Syi’ah di Nusantara: Perkembangan, Pengaruh dan Kesan,” Jurnal Jabatan Sejarah Universiti Malaya (1994), 81; Norarfan bin Haji Zainal, Perkembangan Ajaran Sesat di Negara Brunei Darussalam, (Brunei: Kementerian Hal Ehwal Ugama, Brunei Darussalam, 2007)

${ }^{3}$ See Kamaluddin Nurdin Marjuni, Agenda Politik Syiah: Dendam Warisan dalam Mencari Pemimpin Umat, (Batu Caves: PTS Millennia Sdn. Bhd, 2013); S. Muhammad Naquib al-Attas, Historical Fact and Fiction, (Kuala Lumpur: UTM Press, 2011); Mahayudin bin Yahaya, Sejarah Orang Syed di Pahang, (Kuala Lumpur: Dewan Bahasa dan Pustaka, 1984) ${ }^{4}$ Mahmood Zuhdi Ab. Majid, Abdul Salam Muhamad Shukri \& W. Mohd Azam Mohd Amin, "Konflik Antara Penganut Syiah dengan Pihak Berkuasa Agama di Malaysia,” Kajian tidak diterbitkan, (Putrajaya: Jabatan Kemajuan Islam Malaysia, 2016); Ku Muhammas Asmadi bin Ku Mohd Saad, 50 Soal Jawab Mengapa Syiah Sesat?, (Batu Caves: Al-Hidayah House of Publisher Sdn Bhd, 2014); Nurul Shuhaida binti Mohd Salleh, "The Religious Position of Darul Arqam and Shi'ites in Selangor from the Perspective of Jabatan Agama Islam Selangor (JAIS),” unpublished Master thesis, Islamic Revealed Knowledge (Uî̈l al-DÊn and Comparative Religion), (International Islamic University Malaysia, 2014); Faisal Tehrani, “The Malaysian Shi ‘a: A Preliminary Study of their History, Oppression, and Denied Rights,” Journal of Shi'a Islamic Studies (2013), VI (4): 411-463; Muhammad Asri Yusoff, Syiah Rafidah; Norarfan bin Haji Zainal, Perkembangan Ajaran Sesat di Negara Brunei Darussalam, (Brunei: Kementerian Hal Ehwal Ugama, Brunei Darussalam, 2007); Ashaari Muhammad, Bahaya Syiah, (Kuala Lumpur: Penerbitan Shoutul Arqam 1987).
} 
observation. Using these two methods, this study will ensure the validity of the data and information gained and it will find the latest development of Shi'ism in the region.

By studying this issue Shi 'ism this article led to a proper understanding about the revival of Shi ism, and the factors contributing to the spreading of this ideology among Sunni Muslims in Southeast Asia. Apart from that the study identifies how far Shi'ism had penetrated among the Muslims in the region and to know various responses of the Muslims in the region both from the scholars and the Islamic authorities in the region.

\section{The Revival of the Shi'ah in Southeast Asia in Contemporary History}

Historically, the influence of Shi'ism could be traced along with the arrival of Islam in Southeast Asia since its inception in the 11th century. It could be traced in different aspects socially and culturally as well as in the literature aspect. However, ideologically, it could not penetrate deeply among the Muslims in the region due to the fanaticism of the Muslims to Sunni ideology since the beginning. Shi' ism, however, revives again in modern history at the end of the 20th century to get recognition and acceptance among the Sunni Muslims in the region.

The emergence of Shi'ism in modern times in Southeast Asia could be safely said began from early 1980 after the victory of the Iran revolution by led Imam Sayyid Ruhollah Musavi Khomeini (1902-1989). After the fall of the Shah Iran regime and the emergence of the revolution led by Imam of Shi'ah under the command of Khomeini Shi'ism is getting more popular in the world due to the political domination of Shi'ah movement in Iran. Apart from that the solidness of the Shi'a group to voice out the outcry of the Muslims against the hegemony of West had boosted up the spirit of the Muslims to be a more independent nation. This situation had garnered the support from the Muslims around the world regardless of their ideology be it Shi'ite or Sunni. Shi'ism started to get a place in the heart of the Muslims especially those who came from the non-religious background who had less knowledge about the religion.

Shi' ism backed by huge financial support from the Iranian government begun to spread its propagation in the region by using various ways and methods. Among the effective method used by them is to support the establishment of the Shi'ah forum among the youth in various high educational institutions along with the booming of Islamic revivalism in the campuses in the 80th.

This phenomenon could be found on several campuses especially in Bandung and Jakarta whereby Shi'ite forums had been established led by the former lecturer of Bandung Institute of Technology Jalaluddin Rahmat. Apart from that, the sending of many Indonesian students to Iran especially to Qum University sponsored by the Iranian government contributed to the 'Shi'ite revivalism' in Indonesia. They will be active propagators of Shi'ism among the Sunni Muslims in Indonesia after they graduate from Iran. It started in the early 80th after the success of the Iran revolution that is by sending 10 students which were all from Arab descendants mostly from the YAPI foundation. The number consistently increased year by year and in 2004 it reached 90 students who pursued degree level in mostly Islamic studies at Qum University.

Qum is known as a hub for Shi'ite Islamic education which is normally conducted in colleges known as hawza 'ilmiyya where most of the Shi'ite scholars in Indonesia graduated from these colleges. After their graduation, most of them become renowned Shi'ite teachers in Indonesia and they established education centers in Indonesia as a platform to spread Shi'ite doctrines. Among the popular figures are the twin brother Umar Shahab and Husein Shahab who are actively engaged 
in Shi'ite propagation in Jakarta. ${ }^{5}$

It is worthy to note that most of the earlier followers of Shi'ism in Indonesia are of the Arab descendants originated from Hadramaut, . It is probably there is a link with the Shi'ite followers of the Yemenis where Shi'ism has been practiced by some ethnics of Yemen especially of the Zaidi's sect such as the Al Habsyi ethnic. ${ }^{6}$

For the case of Indonesia that adopts the liberal approach of religion, any ideology enjoys the freedom to be practiced and spread among the people of Indonesia despite the national verdict of the Ulama Council of Indonesia that considered Shi'ism as deviant teaching. This freedom is guaranteed by the constitution which is based on the 45 National Constitution and the Indonesian philosophy of Pancasila.

Another method that contributes to the spreading of Shi'ism in Indonesia is by using freedom of Mass media and broadcasting including radio and television. As example is Al Hadi television broadcast which is mainly used to propagate Shi'ism in Indonesia and the region. The more freedom of broadcasting laws that were adopted by the government of Indonesia since the reformation era in 1998 resulted in the emergence of dozens of broadcasting televisions and radios along with the freedom of using parabola and other receiver technology.

Apart from that the vast access of Internet and smartphone technology added to a new era of communication among the people and ignites the freedom of religious propagation be it moderate or the extremist ideology including Shi'ite ideology. These factors have contributed to the spreading of Shi'ite ideology in Indonesia and most probably in other countries in the region also. The support from the Iranian government in different forms is not less important including financial, cultural and educational support is playing an important role to propagate the ideology.

In brief, the development of Shi 'ism in Indonesia could be divided into four stages; firstly is along with the arrival of Islam in Indonesia despite its weak influence; secondly, post-revolution of Islamic republic of Iran; thirdly through sending of students to Iran; fourthly; the beginning of Shi'ism community in Indonesia by the establishment of Ahlu al-Bait Indonesia (ABI) community in the year 2000 followed by other Shi' ah communities. ${ }^{7}$

Compared to Indonesia the spreading of Shi'ism in Malaysia is rather slow, it is due to the strict rules of mass media and the unilateral management of the Islamic affairs in the country. Mass media in Malaysia is adopting the responsible freedom of broadcasting and by adhering to the rules set by the national and local government. Therefore it has to abide by the national broadcasting acts as well as the local government policy which might be different from one state to another. As for the Shi'ite propagation in mass media in Malaysia and Brunei, it is formally not permitted in line with the policy of the Religious affairs department which restricts the propagation of other ideologies except the Sunni Ash'arite ideology which is adopted as a formal ideology of the country as it is stated in its acts of Religious affairs.

Despite the small number of its followers, Shi'ism had influenced some Muslims in Malaysia and its growth deserves to get attention. The ideology of Shi'ism in Malaysia started to get a foot in 80th after the success of the Iran revolution and took the spirit from that revolution. The

\footnotetext{
${ }^{6}$ Ibid. pp.17-18

${ }^{7}$ Mohd. Hashim, Syi’ah: Sejarah Timbul dan Perkembangannya di Indonesia, Semarang, Journal Harmoni, SeptemberDecember (2012), 11:4, p.31
}

${ }^{5}$ Zulkifli, The Struggle of the Shi'is in Indonesia,(Australia: ANU Press). pp.16-17 
victory of the Islamic theocracy of Iran had boosted the morale of the Muslims in the Muslim world and Malaysia in particular. The common slogan brought by Shi ite that attracted the Muslims is to free the Muslims from the oppression of Western imperialism and to support the Palestinian struggle to free Palestine from the grip of Zionism. Apart from that, the visits by the Iranian envoys formally and informally has some influences on the spreading of Shi'ism in Malaysia. The sending of Malaysian students to study in Iran also as well as the Iranian students studying in Malaysian higher institution had contributed to the dissemination of Shi'ism. ${ }^{8}$

Nowadays, the propagation of Shi'ite ideology has developed in various method that is through individual contacts as well as social media which developed vastly. This way is even more intensive and 'secure' compared to other methods due to the privacy of the relationship as well as it is more difficult to be detected by the religious authority.

There is no particular information on the population of the Shi'ite followers in Malaysia, some said around 5000 while others said double of the that figure. The unknown figure of the Shi'ite followers in Malaysia is due to the sensitivity of the issue as well as the Shi'ite followers the reluctantly declare their faith due to risk that they may face.

As for Selangor state, it has more cases of Shi'ite activities compared to other states in Malaysia. It is probably due to the high numbers of migrants from other states as well as from other countries who stay in the state for various reasons including education, social or economic ones. According to MAIS director, Muhammad Khusrin, the number of Shi'a followers in Selangor had increased rapidly recently, he said:" if a few years ago there were few groups of Shi'ah followers nowadays there are 14-15 groups of Shi'ah spreading around Selangor state from Gombak, Puchong, and Klang. The increase is caused by the pro-active campaign of Shi'a followers which was funded by certain groups especially during the celebration of certain festivals. ${ }^{9}$

He also added that the increase of Shi'ah followers is due to other factors such as social media that contribute to the spreading of Shi'ism and it is difficult to trace. Apart from that their resemblance to the Sunni practice had added the complexity of the issue. ${ }^{10}$

Whereas for the case of Brunei Darussalam as a small Muslim majority country, it declared that the official religion of the Nation is Islam of Ahl as sunnah wa al jama'ah ${ }^{11}$ Consequently, any other theology which is against it be considered wrong and banned from being practiced in the country such as Syi'ah, Bathiniyyah, Khawarij, Murji'ah, Qadiyaniyyah, Bahai, etc. ${ }^{12}$

As stated in its constitution that Islam practiced in Brunei is Ahlu al-Sunnah wa al Jama'ah according to Ash'ari's theology and following mazhab (Islamic law) of Shafi'i and legitimizing the tarekat/tasawuf which is not against the ideology of Sunni. Hence any ideology or sect or mazhab other than the above is considered deviant and subjected to the law enforced by the religious authority and the Sultan as the highest authority.

\footnotetext{
${ }^{8}$ A. Halim Daud, Zarina Othman, Nor Azizan Idris, "Fahaman Syiah dan Keharmonian Agama Islam di Malaysia: Perspektif Pendekatan Keselamatan Negara (Shia and the Harmony of Islam in Malaysia: A Perspective from National Security Approach),” e-Bangi Journal of Social Sciences and Humanities (2018), 13 (3): 1-19 (7), http://ejournal.ukm.my/ebangi/article/view/26946/8279

${ }^{9}$ Astro Awani, 28 January 2020, Gerakan Syi’ah di Selangor Membimbangkan : MAIS, http://www.astroawani.com/beritamalaysia/gerakan-syiah-di-selangor-membimbangkan-mais-229210

${ }^{10}$ Ibid

${ }^{11} \mathrm{Hj}$. Ismail bin Omar Abdul Aziz, Ringkasan Akidah Ahlu Sunnah wa al-jama'ah, (Brunei: Pusat Dakwah Islam, 1994$), 1$.

${ }^{12}$ Ibid
} 
Based on the above constitution, any ideologies other that Ahlu al-Sunnah wa al jama'ah are illegal such as Salafiah, Wahabiyyah, Shi'ism, Muktazilite, Bahaism, Qadiyanism, etc. Consequently, any activities associated to these illegal ideologies are prohibited whether it is related to practice or propagating that ideology and it is subject to the criminal law under the act of causing the disorder or threatening harmony. The Sultan and the religious authority including the Majlis Agama Islam Brunei, The office of Mufti (decree) with the cooperation of the Ministry of Internal affairs will take action on an individual for breaching the law. ${ }^{13}$

For the population of Shi'ite followers in South East Asia generally, there is no precise data could be relied upon due to the sensitivity of the issues. However, Indonesia with the largest number of Muslim population probably has the biggest number of Shi'ah followers despite the unavailability of the solid data. It is due to the freedom of religion policy adopted by the government and the freedom of propagation of all religions and sects. There are different opinions about its number, according to government data, Shi'ite followers in Indonesia are around 500 while according to the Syura council of Ahlu al-Bait association of Indonesia Jalaluddin Rahmat the population of Shi'ite followers is around 2.5 million. The Syi'ah community could be found in different areas including West Java, Central Java, East Java, and Madura island according to his statement when he spoke to Tempo on Thursday 29 August 2012. ${ }^{14}$

According to Umar Shihab the chief of Ahlu al Bait Indonesia, ABI was established in 2010 and now it has 24 provincial branches and 120 sectoral branches across Indonesia despite the unclear number of the followers of Shi'ah. There is no census done so far to know the population of Shi'ite in Indonesia and it is said around 5 million whilst some others said between 1 to 2 million. ${ }^{15}$

Despite this significant number of its followers, the Shi'ite community didn't declare themselves as Shi'ite followers openly and they prefer to hide their identity (taqiyya) due to the risk that they may encounter if they are identified as Shi'ite followers. Few amok cases took place in Indonesia that involved Shi'ite followers such as in Sampang, Madura whereby the Shi'ite village was rampaged and attacked by the Sunny followers in 2012 due to their ' deviance from the common Sunni ideology. That is why the Shi'ite followers in Indonesia tend to cover themselves and behave as other Muslims and it is not easy to recognize them as Shi'ite followers.

This number is also shared by the Chief of Syura council of Ahlul Bait Indonesia (ABI) Umar Shahab who claimed that the Shi'ite followers reach millions in his statement at the talk on 'Shi'ite, sectarianism and Geopolitics" held in Ma'arif Institute, Jakarta in early 2016. He reiterated that Shi'ite communities could be found in almost all big cities in Indonesia up to Papua island. He added that the spread of Shi'ism was caused by the widespread of books on Shi'ism as well as the propaganda against it that led people to know about Shi'ism instead of scaring the people of Shi'ism.

\footnotetext{
${ }^{13}$ Tim Ahlul Bait Indonesia, Syiah menurut Syiah, Jakarta, Ahlul Bait Indonesia, 2014, pp. 403-404

${ }^{14}$ Tempo co., 3Sept. 2012. Kisah Kang Jalal soal Syiah di Indonesia. https://nasional.tempo.co/read/427062/kisah-kang-jalalsoal-syiah-indonesia-bagian-1/full\&view $=$ ok

${ }^{15}$ Ibid
} 
Muharram festival which is one of the important events among the Shi'ite followers to celebrate the incident of Imam Hussein murder in Karbala 14 centuries ago could be held in some areas in Indonesia despite the opposition of the majority Muslims in Indonesia. However, in some cases, the celebration could be canceled due to the threat received by the committee if they proceed with their plan. The most regular Muharram festival had been held in the Islamic Cultural Centre in Pejaten South Jakarta since its establishment in 2003. Hundreds of men and women clad with black shirt coming from different places in Jakarta and the surrounding area flock to the center to celebrate the festival of Muharram as a sign of condolence of the murder of the Prophet's grandson. The center was built by the sponsorship of the Iranian government in 2003 and originally functioned as a cultural center for research and publication. It consists of 2 floors with the first floor is used as al Husainiyyat (Shi'ite's mosque) that could accommodate few hundreds of visitors at one time and normally used by the visitors to pray and to have a discussion on various issues especially a study of Shi'ism by the Shi'ite community in Jakarta. ${ }^{17}$

\section{The Responses of the Muslim Scholars and the Islamic Authorities to Shi'ism in Indonesia, Malaysia and Brunei}

The issue of Shi'a has sparked various responses among the Muslims in South East Asia in general since its re-emergence in the early 90th. These responses differ from one to another due to the complexity of the issue and the different perspectives on Shi'ism as well as the issue of human rights which is recently promoted along with the era of democratization. Southeast Asia region is generally dominated by the Sunni ideology since the arrival of Islam in this region in the 11th century despite the emergence of the Shi'ite ideology in its history.

As for the case of Malaysia, Shi'ism and other non-Sunni ideologies are considered illegal according to the National Fatwa Council of Malaysia and according to the local religious authorities of Malaysia. By having the uniformed national decree on the issue, the religious authority in Malaysia could take an action if there are any activities conducted by a certain group or sect which is again the formal ideology of the country.

The adoption of Sunni doctrines in Malaysia is clearly stated in the National Islamic verdict issued in May 1996 that declared Ahl al Sunnah wa al- jamÉ'ah as the only acceptable Islamic doctrine in Malaysia while other sects or groups are considered deviant and consequently its practice and propagation is prohibited. ${ }^{18}$

As an example, 22 persons in Gombak Selangor suspected to be Shi'ite followers had been charged in the Islamic court of celebrating the Karbala incident in Muharram. The custody is done according to sect. $12 \mathrm{C}$ enactment of Islamic Criminal Law of Selangor 1995. Upon the conviction these individuals could be fined not more than Rm 3000 or detention less than 2 years or both together according to Azlinda, the JAIS speaker said. This action is done based on the Selangor Islamic verdict issued on 17 Oct. 2013 stating that Shi'ism is against and contradicting Islamic teaching and the Sunni doctrine.

\footnotetext{
${ }^{17}$ Rina Khatijah, Mengintip Warga Syiah di Jakarta menyambut Asyura', Berita Benar, 20/9/2018

https://www.benarnews.org/indonesian/berita/syiah-asyura-09202018120625.html

${ }^{18} \mathrm{Ibid}, \mathrm{p} .137$
} 
The restriction of Shi'ah activities had started since 1996 by the National fatwa council followed by 11 state religious offices that enforced the decision. Several incidents took place since then such as on Aug 31, 2018, where more than 50 people believed to be Shi'ah followers in Kota Bharu Kelantan were detained by Kelantan Islamic Affairs and Religious Department (Jahaeik) and the police corp. While in Selangor JAIS had raided several functions believed to be organized by the Shi'ah community in 2019 including the Gombak incident as mentioned above. This incident had been confirmed by the Minister in the Prime Minister office Dr. Yusuf Rawa by asserting that the raid had been conducted according to SOP of Jais. ${ }^{19}$

However, these incidents had received different response by the human rights watch (Suaram) which considered that these actions and detentions without trial are against the freedom of religion as guaranteed by the constitution of Malaysia. ${ }^{20}$

The 1996 decree on the deviation of Shi'ism had received different responses from the public and there is voice of demand to review it. The review is to avoid other parties to take the chance to exploit the differences among Muslim society. "Shi'ism can be practiced but not to spread it out", said Pulau Pinang Mufti Datuk Dr. Wan Salim. He also argued that the opinion on Shi'ism as deviant from Islam doesn't represent the opinion of the majority of Sunni scholars. It is based on the fact that the practice of the Shi'ite is still within the boundary of Islam. The decision could be reviewed and to consider Shi'ite as Muslims. However, he suggested that Shi'ism should be practiced privately because it could create confusion among the Sunni Muslims due to its different teachings ${ }^{21}$. This statement came as a response to the demand for reviewing the 1996 decree saying that Shi'ite is deviant from Islam.

On the other hand, some academicians voiced out their opinion on the issue of minority such as Shi' ite community. It is said that Malaysia has become an intolerant Muslims nation and they are urging Malaysian Muslims to speak up as a response to the ongoing persecution against the minority Shi'ah Muslims in the country, said Prof. dr. Syed Farid Al atas, a professor of Sociology at the National University of Singapore. Shi'ah Muslims were banned in Malaysia as they were seen as deviant, he added.

He suggested that the minister in the PM department Datuk Seri Dr. Mujahid Rawa to voice out against such incident otherwise Malaysia will be seen as an extreme Islamic country that does not tolerate the minority, he said at a forum entitled "The Future of the Ummah: Voices of Unity and Harmony" on Saturday (Sept 28, 2019). ${ }^{22}$

\footnotetext{
${ }^{19}$ Muh. Hafis Nawaei, “22 Pengikut Syiah ditahan”, Harian Metro, Sept., 7,2019, https://www.hmetro.com.my/utama/2019/09/494256/22-pengikut-syiah-ditahan 20 lbid.

21 M. Yusri Muzarim, "Fatwa terhadap Syiah Boleh Disemak Semula : Mufti Pulau Pinang", Berita Harian Online 19/11/2019, retrieved from https://www.bharian.com.my/berita/nasional/2018/11/499710/fatwa-terhadap-syiah-boleh-disemaksemula-mufti-pulau-pinang

${ }^{22}$ Hemananthani \& Fatimah Zainal," Academic: Persecution of Shiahs shows M'sian becoming more Intolerant nation". The Star online, Sept.28, 2019. https://www.thestar.com.my/news/nation/2019/09/28/academic-persecution-of-syiahsshows-m039sia-becoming-an-intolerant-muslim-nation
} 
Whilst Dr. Chandra Muzaffar the president of Just World (JUST) and Dr. Ahmad Farouk Musa the founder of the Islamic Renaissance Front commented that the Ulama of Malaysia should open their minds to understand the Shi'ah Muslims in the country who were subject to arrest and infringement of their rights. He added that there were segments of ulama in Malaysia who are irrationally antiShi'ah who are practicing their rights and not propagating it. ${ }^{23}$

Furthermore, Dr. Ahmad Farouq said in South Asia, where there were substantial Syi'ah minorities there was no large scale Sunni-Shi'ah conflicts until the last decade or so and he suggested that by understanding geopolitics nowadays the Muslim governments whether Sunni or Shiite should respect the rights of their citizens irrespective of their religious belief. He added that the Muslim countries should desist from using religion as an instrument of security and foreign policy and instead focus on practical ways of resolving conflict. 24 "Muslim governments," he added, "should also prevent any hate speech towards Muslim minorities in their country." 25

On the other hand, Prof. Osman Bakar said that to promote unity and harmony in Muslim countries, three major knowledge should be introduced namely philosophy, Sufism and maqasid Shari'ah in their education system. He suggested that there is no diversity without unity, there must be space to constituents of the diversity.

On another occasion, Dr. Farid al Attas rebuffed the statement of Saudi Embassy officer in Malaysia recently saying that it is meaningless to approach Shi'ite and to build unity with Shi'ite because they are deviant. He asserted that to regard Shi'ite as the enemy of Islam is against the verdict of orthodox Sunni. Such an opinion is influenced by the extreme ideology of Wahabism and this ideology is very hostile to Syi'ah. He elaborated further that despite the differences of creed and some other issues, the majority of Sunni scholars never declared that Shi'ite is infidel and support hostility against them. He criticized the Malaysian government for disregarding the hatred voice against the minority groups especially the Shi'ite. ${ }^{26}$

A memorandum was sent to the Yang Dipertuan Agung (Supreme head of the King) by the Shi'ite community in Malaysia in 2011 demanding the amendment of the 1884 decree declaring that Shi'sm is deviant and out of Islam. They appealed that Shi'ah community to be accepted as Muslims and to give them the freedom to practice their religion and faith. ${ }^{27}$

As a response to the demand to rectify the 1996 decree on Shi'ism the Minister in the PM office reacted and stated that to amend the decree is under the jurisdiction of the State religious authority and it is not within the capacity of the Ministry to amend it.

Compared to Malaysia Shi'ism in Indonesia had enjoyed a better situation in terms of freedom and right despite the intimidation from the public in some cases. According to the Indonesian constitution 1945, any Indonesian is guaranteed to practice any religion or faith and the constitution doesn't interfere with the religious affairs of the people. However, any religious activities should not disturb the peace and harmony of the public and whoever violates these rules could be charged accordingly. Although Indonesia is a Muslim majority country it adopts the secular approach in its religious affairs that is by separating the religious affairs and legal aspects. The

23 Ibid.

${ }^{24}$ Ibid

25 Ibid

${ }^{26}$ Nur Hasliza Saleh, “Dakwaan Syiah Musuh Islam Langgar tradisi asal Sunni: Ahli Academic”. MSNnews, 8/1/2020

${ }^{27} \mathrm{Al}$ ahkam.net, retrieved from http://www.al-ahkam.net/home/memorandum-majlis-syiah-malaysia-kepada-yang-dipertuan -agong-malaysia 
ministry of religious affairs is not dealing with the enforcement or execution of the decision or decree which is issued by the Religious authority such as the Ulama Council or any other organizations.

Consequently, the Shi'ah community in Indonesia could practice their faith and worship despite the pressure or even intimidation from different parties especially the Sunni Muslim as the majority in the country. They can freely practice their ideology or even propagate it by all means without limit except if it is objected by the public or by mass protest.

In many cases, the Shi'ite community of Indonesia encountered intimidation and even harsh confrontation from the Sunni Muslims due to their 'strange' ideology especially during the Shi'ite celebration of Muharram. The celebration of Muharram in Bogor and Balikpapan, East Borneo in 2015 had to be canceled due to the protest of the local authority and the mass protest.

According to the city council, Bima Arya the cancellation was due to the threat from people that could spoil the peace and harmony among the Muslims in the Bogor area. They also banned the Shi'ite followers from other areas to come to Bogor for the reason that it could threaten the harmony of the people..$^{28}$

As a response to that case, the Ulama Council of Indonesia (MUI) issued a statement that MUI can only appeal to the public to be aware of the influence of the extreme Shi'ite among the society namely Shi'ite Ghulat and Rafidhah. These two sects according to the majority of Muslim scholars are out of Islam whilst other sects of Shi'ite are still considered part of the Islamic mazhab.

"It is a wrong perception among the Muslims to generalize all sects of Shi'ite is wrong and out of Islam and this misconception should be corrected in these days where certain parts want to ignite the conflict between Sunni and Shi'ite in Indonesia", Muhyiddin said. He also added that there is no Muslim country that issued the decree on the deviation of the Shi'ite ideology and there are around 15 percent of Shi'ite in Saudi Arabia. ${ }^{29}$

The secretary of Ahl al-Bait Indonesia Ahmad Hidayat criticized the decision of the banning of such celebration that it is a disaster to the pluralism and diversity of Indonesia of which such activity is guaranteed by the constitution. He also condemned the action taken by the police who canceled the celebration and supposed they should handle the mass who threatened the freedom of religion. ${ }^{30}$

On the other the speaker of Ministry of Religious Affairs of Indonesia through its DirectorGeneral of Islamic affairs Juraidi said that the current issues of intimidation and oppression and harassment against the Shi'ite followers should be referred to Islamic council of Indonesia (MUI) because it is not within his prerogative to issue a decree of whether Shi'ism is deviant or not (from Islamic teaching). ${ }^{31}$

He stressed that the highest authority of religious affairs in Indonesia is the Ministry of Religious Affairs and Ulama Council of Indonesia (MUI), however, on the issue of ideology and religious matter the Ministry will refer to the Ulama Council (MUI) whilst the Ministry is in charge

\footnotetext{
${ }^{28}$ Tempo.co” Kelompok Syiah di Yogy diancam Diseran”. Tempo.co.id.Nov.22,2013. https://nasional.tempo.co/read/531705/kelompok-syiah-di-yogya-diancam-diserang

${ }^{29}$ BBC Indonesia,” Ajaran Syiah, Menurut MUI tidak dilarang di Indonesia”, BBC News Indonesia,

26/10/2015https://www.bbc.com/indonesia/berita_indonesia/2015/10/151025_indonesia_syiah_bogor

${ }^{30}$ Ibid

${ }^{31}$ Almer Sidqi, “Syiah Dituding sesat, Kemenag serahkan ke MUI”, Gatra.com, 29 Nov.

2019https://www.gatra.com/detail/news/459409/politik/syiah-dituding-sesat-kemenag-serahkan-ke-mui
} 
of administering the religious matters. He said that when he commented on the Shi'ite issue at the seminar of Ahlu al-Bait Indonesia in Jakarta on 29/11/2019.32

"MUI is the right authority to handle the issue because it consists of the representatives of all Islamic organizations in Indonesia whilst the Ministry is playing the role to give guidance and monitoring the situation depending on the issue and conflict that occurred in the society", he added. ${ }^{33}$

Among the methods that the Shi'ite community in Indonesia used are: public talk, mass media, electronic media such as radio and television, social media and nowadays they used satellite TV as well as live streaming broadcast. It can be easily accessed by the public despite the rejection of the Sunni majority but they could not stop it due to the constitution that protects the freedom of religion.

The only way for the Muslims in Indonesia to express their dissatisfaction with the religious matters is by forwarding their grievances to the authority on the bases of creating public unrest which is hardly applicable. The other way is to refer it to the Ulama Council or to the organizations that they affiliated to such as Muhammadiyyah or Nahdhatul Ulama.

On the other hand Nahdatul Ulama as the biggest Islamic organization that bears the flag of Ahlu as-Sunnah wa al jama'ah (Sunni) in its response to the issue of Syi'ah they refer to the statement of its founder KH Hasyim Ash'ari that out of the four mazhab of Sunni and the two mazhab of Syiah namely Zaidiyyah and Jakfariah they are considered the follower of Bid'ah and it could not be followed. ${ }^{34}$

The opinion is also reconfirmed in the manual book of Nahdatul Ulama (2007) that the Sunni mazhab does not accept the underground groups which such as Shi'ah or LDII (Lembaga dakwah Islam Indonesia). ${ }^{35}$

The stand of the highest Islamic authority of Indonesia Muslim Scholars Council of Indonesia (MUI) also advocated that Shi'ism is not prohibited in Indonesia but it warns the Muslims of Indonesia to be aware of the spreading of extreme Shi'ite. This statement was given by the chief of foreign affairs of MUI Muhyiddin Junaidi on responding to the circular issued by the Bogor city council on 22nd October 2015 that banned any Ashura celebration by Shi'ite followers in his municipal. ${ }^{36}$ According to Muhyiddin Junaidi by referring to the decision of MUI year 2004, MUI has no position to say that Shi'ah is deviant. ${ }^{37}$

On the other hand, in the 3rd congress of Ahlu al-Bait Indonesia held in Jakarta last November, its leader Umar Shahab said: "Shi'ah community is just an integral part of the Muslims in Indonesia that is why we don't identify ourselves as Shi'ah because we are part and parcel of the Muslim ummah and there is no distinction despite some differences that we have from the others,

\footnotetext{
32 Ibid.

${ }^{33}$ Ibid

${ }^{34}$ Hasyim Asyari, Mukaddimah Qanun Asasi Nahdatul Ulama 1926. http://nu1926.blogspot.com/2011/05/mukadimahqanun-asasi.html

${ }^{35}$ LDII is an Islamic organization which was established in 1972 which was known as Lemkari. Established by 5 people as a social organization. Its famous leader was Hasan Abu Ubaidah lived in East java it is characterized by its exclusiveness and strict discipline and hidden agenda. It has a well-structured organization and its members are various such as farmers, traders, civil servants, and others and they have secret discussions and learning agendas. They build their mosques and suraus within its community which is normally isolated from the rest of Muslims.

${ }^{36}$ BBC Indonesia, “Ajaran Syiah Menurut MUI tidak Dilarang”, BBC News Indonesia, 25/10/2015

https://www.bbc.com/indonesia/berita_indonesia/2015/10/151025_indonesia_syiah_bogor

${ }^{37}$ Ibid
} 
we don't feel we are a minority because we are an integral part of Muslims which cannot be separated from them" he added. ${ }^{38}$

On the same occasion the Director of information, ministry of Religious affairs Juraidi welcomes such activity and he hoped that the Shi'ah community in Indonesia could contribute to the nation-building especially in religious aspects. ${ }^{39}$

He further stressed that according to the national philosophy of Indonesia, Pancasila is the right choice to absorb the diversity of Indonesian population that consists of different tribes, culture, languages, and religions. Pancasila is binding the nation to be one nation and ABI community could contribute to developing a good culture of Indonesia. ${ }^{40}$

Based on the constitution of Indonesia and its interpretation as elaborated above it is understood that Shi'ism is not an illegal organization in Indonesia and it could be practiced by its followers as long as the organization is registered and it doesn't violate the laws.

The statement on Shi'ism by the Grand Sheikh of Al Azhar during his visit to Indonesia in 2016 has sparked the debate among the Muslims in Indonesia. However, it was seen as cool water for the Shi'ite community in Indonesia who want to be accepted by the Muslim society while for the Sunni Muslims it was a lenient stand of the Sheikh on the Shi'ism issue.

In his six-day visit to Indonesia, he declared that Sunni and Shi'ite are Muslim brothers, there is no fundamental principle that brings the Shi'ites out of Islam. This statement was pronounced as a response to the question forwarded to him during the meeting in the office of MUI (Ulama council of Indonesia). He elaborated that Islam has a clear definition that is by declaring shahadah, performing solah, paying zakah, fasting in Ramadan and performing Hajj for those who can afford it. Whoever fulfills these pillars he is regarded as Muslim unless he/she denied them. "There is no fundamental principle that could bring Shi'ite out of Islam and there are lots of similarities between Sunni and Shi'ism and the only difference between them is on the issue of Imamah", he added. According to Shi'ite imamah (leadership) is considered the foundation of religion whilst for Sunni is it a branch of religion" he added. ${ }^{41}$

In the Indonesian context, the Grand Sheikh said that Indonesia as the biggest Muslim country he hoped Indonesia could be a pioneer in realizing the huge task of unifying the nation with diverse culture, mazhab, and sects.

The statement, however, is considered a moderate stand of al Azhar as a center of the Sunni mazhab whereby it was established by the Shi'ite Fatimid empire in Egypt. The statement is seen to be inclined more towards reconciliation rather than confrontation between the two biggest sects of Muslims. Perhaps this opinion is also to ease the tension between the Sunni and Shi'ite mazhab in the shadow of extensive conflicts that are taking place in Middle East countries despite the criticism that may arise from the Muslims in South East Asia.

The statement of Grand Sheikh perhaps more or less in line with the opinion of MUI earlier which initially never declared that Shi'ite ideology is out of Islam (apostasy). This opinion was published by MUI in its National workshop held in March 1984 that states as below:

${ }^{38}$ Rahil Narda, “Gelar Muktamar ketiga, Ahlul Bait: Syiah Bagian Integral Umat Islam RI”, Detik.com, Nov.29, 2019

${ }^{39} \mathrm{Ibid}$

${ }^{40} \mathrm{Ibid}$

${ }^{41}$ Solah Salim, “Inilah Pernyataan Syeh Azhar Tentang Syiah dan Toleransi”. Hidayatullah.com. Feb. 24.2016 https://www.hidayatullah.com/berita/internasional/read/2016/02/24/89996/inilah-pernyataan-syeikh-al-azharmengenai-syiah-dan-ekstrimisme-di-mui.html 
- Shi'ite ideology is the ideology that exists in the Muslim world differed from the Sunni ideology which is followed by the Muslims in Indonesia. The differences are as follow:

- $\quad$ Shi'ite rejects the hadith not reported by Ahlu al-Bait ( family of the Prophet) while the Sunni doesn't differentiate that as long as the hadith is reliable according to the science of hadith.

- Shi'ite believes that Imam/leader is infallible whilst the Sunni believes that no one is infallible except the Prophet PBUH.

- $\quad$ Shi'ite doesn't accept ijma' (consensus) without Imam (leader) whilst the Sunni accepts it even without Imam.

- Shi'ite believes that the appointment of Imam is a fundamental issue whist the Sunni believes that the appointment depends on the general interest (maslahah) to protect the religion and the Muslims.

- $\quad$ Shi'ite generally doesn't acknowledge the four caliphs except for Ali r.a. after the Prophet whilst the Sunni acknowledges them all together.

In the end, due to these differences, MUI recommends Muslims to be cautious about the ideology of Shi'ism and its influence.

Looking at the statement above it is understood that MUI as the highest religious authority of Indonesia is lenient in its stand to Shi'ism ideology which may reflect the National ideology that is to protects the freedom of faith. The statement of the Grand Syeikh had been responded positively by the Shi'ite community in Indonesia. They welcome such opinions that appreciate the existence of Shi'ism and freedom of opinion. Dr. Umar Shihab in his letter to the Grand Sheikh said that Ahlu alBait Indonesia welcome such an opinion that could bring the unity and integration of the ummah and it is what they hoped as a minority sect in Indonesia. He appreciated and praised such moderate opinion which is important to bring peace and harmony among the Muslims in general and the Indonesian nation in particular amidst the clash and conflicts among the Muslims world widely that disintegrate the unity of the Muslim nation. ${ }^{42}$

On the other hand, the Muhammadiyyah organization which was previously firm in its stand towards Shi'ism, however, it seems to be more relaxed towards the Shi'ite community recently. It was reflected in its last congress in Makassar in 2015 by showing sympathy towards the oppression of the Shi'ite community in Indonesia and the current conflicts in Middle east countries by calling for a dialogue between Sunny and Shi'ite. In its decision of the Muktamar (congress) the committee issued a manual book on the conclusion of the muktamar and declared the necessity of a dialogue between Sunni and Shi'ite. The internal dialogue is meant to build a mutual understanding of the similarities and to tolerate the differences between Sunni and Shi'ite and to develop a sense of affection and commitment to building a constructive effort in building a civilization. ${ }^{43}$

This new stand of Muhammadiyyah, however, had received criticism from some Muslims, it had been interpreted that Muhammadiyyah had been influenced by the liberalist and pluralist ideology brought by its new generation. It has been perceived that Muhammadiyyah had accepted Shi'ism as it doesn't show strong criticism toward Shi'ism and it is more lenient toward the ideology.

This opinion is not much different from the opinion of Din Syamsuddin the former chief of the organization when he responded to the statement of MUI of East Java on the deviation of Shi'ah from Islam. He criticized the statement by arguing on what reason the MUI issued the decree as we

${ }^{42}$ Dr. Umar Shihab, "Surat Resmi Ahlu al-Bait Indonesia kepada Syeikh al Azhar", SyiahIndonesia.net.9 Agustus 2016.

${ }^{43}$ Tanfidz Keputusan Muktamar Muhammadiyah ke 47, Makassar Sept. 2015. 
all know that Sunni and Shi'ite are both Muslims as they declared the same shahadah (Islamic declaration). Both mazhab have a lot of similarities as well as differences and we should build up tolerance rather and conflict. These differences arose from the critical thinking of the Muslims and it should not be disputed. ${ }^{44}$

As information MUI (East Java branch) had issued a decree in 2012 that Shi'ism is a deviant sect from Islam according to the decree no SKF/MUI-JTM/1/2012. According to MUI of East Java, the decree was issued corresponding to the decree of MUI national Jakarta year 1984 on the deviation of Shi'ite ideology. This decree is confirmed and no one could amend it without the unanimous agreement of the Ulama Council of East Java, said M. Yunus the general secretary of MUI of East Java. ${ }^{45}$

Based on the above opinions it could be concluded that Shi'ism in Indonesia is enjoying more freedom and has more room to spread. It is due to the national constitution that guarantees the freedom for all religions and all religious teachings could be practiced regardless of whether it is Islamic sects or other religious sects.

Compared to Indonesia, in Malaysia and Brunei Shi'ism is more restricted due to the interference of the Religious authority and the act that confined Sunni as the only mazhab adopted and practiced by the Country. Apart from that, the uniformity of the system of the religious authority in these two countries contributes to the uniformity of verdict and decision. Furthermore, the Sultan administers the religious matter as the highest authority, which has legal consequences that could be applied to anyone, infringes the sanctity of the $\mathrm{law}^{46}$. Whilst in Indonesia the religious affair is not enforced by law and there are no legal consequences for the offender unless the case falls under civil law which regulates all matters in general. The act is related to religious blasphemy and it applies to all religions without distinction.

\section{CONCLUSION}

From the above discussion, we can conclude that Shi'ism in Southeast Asia is considered a new issue that started in the early 80th onward after the success of the Iran revolution. By then Shi'ism began to get a foothold in the region through various methods such as sending the students to Iran, Iranian propagation and financial assistance to the region as well as the cooperation between the Shi'ite communities between Iran and in the region. The growing number of Shi'ite populations in the Region has roused major concern among the Sunni dominant Muslims in the region. It is because Shi'ism is new to them and it brings a new perception of Islam and different practices. Muslim scholars and religious authorities in the region had shown different responses to Shi' ism. Some countries had responded firmly to the spreading of Shi'ism while the other shows are more lenient to the ideology. This is due to their concern of conflict among the majority Sunni Muslims in the region if the number of the Shi'ite population is growing significantly as it happened to the

\footnotetext{
${ }^{44}$ Aditya Rivanor, “Din: Muhamadiyah Keberatan Fatwa Syiah Sesat”, Kompas, 7/9/2012

${ }^{45}$ Ibid

${ }^{46}$ Perkara 3(5) menyebut, tiga institusi berkaitan Islam di Wilayah Persekutuan: Yang di-Pertuan Agong sebagai ketua agama Islam; Parlimen sebagai badan perundangan yang berhak membuat undang-undang berkaitan hal ehwal Islam dan Majlis Agama Islam, institusi yang dibuat oleh Parlimen melalui sebuah undang-undang untuk menasihati Yang di-Pertuan Agong dalam perkara berkaitan Islam.
} 
Muslims in the Middle East region. On the other hand, these countries are also bound to the freedom of faith, which is guaranteed by United Nation constitution as well as by the ruling governments in Southeast Asia. After all the issue of Shi'ism has opened up the new horizon among Muslims in the region and its existence could not be denied as it happened to other Muslim countries also. However, the issue needs wise and careful responses due to its complex nature that also involves social, economic and political factors.

\section{Biography:}

The writer received his Ph.D. from APIUM in 2009 in the field of Aqidah and Islamic thought. His major field is in theology and contemporary Islamic thought. Currently $\mathrm{He}$ is working with International Islamic University under the department of Fundamentals and Interdisciplinary Studies. His research covers various subjects ranging from theology, comparative religion, halal issues, deviant sects, as well as the Islamization of knowledge issues.

\section{References}

[1] A. Halim Daud, Zarina Othman, Nor Azizan Idris, "Fahaman Syiah dan Keharmonian Agama Islam di Malaysia: Perspektif Pendekatan Keselamatan Negara (Shia and the Harmony of Islam in Malaysia: A Perspective from National Security Approach), e-Bangi Journal of Social Sciences and Humanities (2018), 13 (3): 1-19, http://ejournal.ukm.my/ebangi/article/view/26946/8279

[2] A. Hasjmy, (ed.), Sejarah Masuk dan Berkembangnya Islam di Indonesia,.Bandung: Alma'arif, 1981

[3] Abdul Rahman Haji Abdullah, Pemikiran Umat Islam di Nusantara: Sejarah dan Perkembangannya hingga abad ke 19.Kuala Lumpur: Dewan Bahasa dan Pustaka, 1990.

[4] Ahmad Zuhdi Ismail, Imam Ja'far al-Sadiq: Pemikirannya Tentang Konsep Ketuhanan. Kuala Lumpur: Penerbit Universiti Malaya, 2006.

[5] Al ahkam.net, retrieved from http://www.al-ahkam.net/home/memorandum-majlis-syiah-malaysia-kepada -yang-dipertuan-agong-malaysia

[6] Al-Shahrastani, Muslim Sects and Division, trans. A. K. Kazi \& J. G. Flynn, (London: Kegan Paul International, 1984); Arabic Al-Milal wa al-NiÍal, 3 vols., al-Qahirah, n.d.

[7] Ashaari Muhammad, Bahaya Syiah,. Kuala Lumpur: Penerbitan Shoutul Arqam, 1987

[8] Astro Awani, , “Gerakan Syi'ah di Selangor Membimbangkan : MAIS”, 28 January 2020

http://www.astroawani.com/berita-malaysia/gerakan-syiah-di-selangor-membimbangkan-mais-229210

[9] Ayoub, Mahmoud, Redemptive Suffering in Islam: A Study of the Devotional Aspects of (Ashura) in Twelver Shi'Ism.. The Hague: Mouton, 1978

[10] BBC Indonesia, “Ajaran Syiah Menurut MUI tidak Dilarang”, BBC News Indonesia, 25/10/2015. https://www.bbc.com/indonesia/berita_indonesia/2015/10/151025_indonesia_syiah_bogor

[11] Daftary, Farhad, The Ismailis: An Illustrated History. London: Azimuth Editions in association with the Institute of Ismaili Studies, 2008.

[12] Donaldson, Dwight. M., The Shi' ite Religion. London: Luzac and Co., 1933.

[13] Faisal Tehrani, "The Malaysian Shi'a: A Preliminary Study of Their History, Oppression, and Denied Rights,” Journal of Shi‘a Islamic Studies (2013), VI (4): 411-463

[14] Fyzee, Asaf A. A., A Shi’ite Creed. Tehran: World Organization for Islamic Services, 1982

[15] Halm, Heinz, Shiism. Edinburgh: Edinburgh University Press, 1991

[16] Hasyim Asyari, Mukaddimah Qanun Asasi Nahdatul Ulama . NU Press 1926.

[17] Hazleton, Lesley, After the Prophet: The Epic Story of the Shia-Sunni Split in Islam.New York: Doubleday, 2009. 
[18] Hj. Ismail bin Omar Abdul Aziz, Ringkasan Akidah Ahlu Sunnah wa al-jama'ah, (Brunei: Pusat Dakwah Islam, 1994), 1.

[19] Jafri, S. H. M., Origins and Early Development of Shi'a Islam. Oxford: Oxford University Press, 2000.

[20] JAKIM, Penjelasan terhadap Fahaman Syiah, Kuala Lumpur: Jabatan Kemajuan Islam Malaysia, 1997.

[21] Kamaluddin Nurdin Marjuni, Agenda Politik Syiah: Dendam Warisan dalam Mencari Pemimpin Umat,. Batu Caves: PTS Millennia Sdn. Bhd., 2013.

[22] Ku Muhammas Asmadi bin Ku Mohd Saad, 50 Soal Jawab Mengapa Syiah Sesat?, Batu Caves: AlHidayah House of Publisher Sdn. Bhd., 2014.

[23] Mahmood Zuhdi Ab. Majid, Abdul Salam Muhamad Shukri \& W. Mohd Azam Mohd Amin, "Konflik Antara Penganut Syiah dengan Pihak Berkuasa Agama di Malaysia,” Kajian tidak diterbitkan. Pura Jaya: Jabatan Kemajuan Islam Malaysia, 2016.

[24] Momen, Moojan, An Introduction to Shi'i Islam: The History and Doctrines of Twelver Shi'ism. Yale: Yale University Press, 1985.

[25] Muhammad Asri Yusoff, Ibn Ishaq: Peranannya dalam Penyebaran Fahaman Syiah di kalangan Ummah. Kota Bharu: Pustaka Bisyarah, 2004

[26] Muhammad Asri Yusoff, Syiah Rafidah: Di antara Kecuaian Ulama’ dan Kebingungan Ummah, (Kota Bharu: Pustaka Bisyarah, 2010.

[27] Nasr, Seyyed Hossein, Expectation of the Millennium: Shi'ism in History. Albany: State University of New York Press, 1989.

[28] Nawbakhti, Abu Muhammad al-Hasan b. Musa al-, KitÉb firaq al-ShÊ'ah,. al-Qahirah: Dar al-Rashad, 1992.

[29] Norarfan bin Haji Zainal, Perkembangan Ajaran Sesat di Negara Brunei Darussalam, (Brunei: Kementerian Hal Ehwal Ugama, Brunei Darussalam, 2007.

[30] Nur Hasliza Saleh,”Dakwaan Syiah Musuh Islam Langgar tradisi asal Sunni: Ahli Academic”. MSN news, $8 / 1 / 2020$.

[31] Nurul Shuhaida binti Mohd Salleh, "The Religious Position of Darul Arqam and Shi'ites in Selangor from the Perspective of Jabatan Agama Islam Selangor (JAIS),” unpublished Master thesis, Islamic Revealed Knowledge (Usul al-Din and Comparative Religion). Gombak: International Islamic University Malaysia, 2014.

[32] Pejabat Mufti Wilayah Persekutuan, Membendung Pengaruh Syiah. Kuala Lumpur: Pejabat Mufti Wilayah Persekutuan, 2011.

[33] Pusat Pengajian Umum, “Aspek Persamaan dan Perbezaan,” Prosiding Seminar Ahli Sunnah dan Syiah Imamiyyah, Bangi: UKM, 1996.

[34] Rahil Narda, "Gelar Muktamar ketiga, Ahlul Bait: Syiah Bagian Integral Umat Islam RI”, Detik.com, Nov.29, 2019

[35] Shahabi, Mahmud, "The Roots of Shi' ism in Early Islamic History,” in Shi'ism Doctrines, Thought and Spirituality, ed. Syed Hossein Nasr, Hamid Dabashi et al,. New York: State University of New York Press, 1988.

[36] Tabatabaei, Sayyid Mohammad Hosayn, Shi'ite Islam, trans. Seyyed Hossein Nasr.Albany: State University of New York Press, 1975.

[37] Tempo co., 3Sept. 2012. "Kisah Kang Jalal soal Syiah di Indonesia”. Tempo.co.id. https://nasional.tempo.co/read/427062/kisah-kang-jalal-soal-syiah-indonesia-bagian-1/full\&view=ok

[38] Tempo.co. "Kelompok Syiah di Yogya diancam Diserang”. Tempo.co.id.Nov.22,2013. https://nasional.tempo.co/read/531705/kelompok-syiah-di-yogya-diancam-diserang

[39] Tim Ahlul Bait Indonesia, Syiah Menurut Syiah. Jakarta, Penerbitan Ahlul Bait Indonesia, 2014.

[40] VOA Islam, “Tokoh Syiah klaim jumlah penganut Syiah Jutaan orang”, VOA Islam, Feb.21.2016.

[41] Wan Mohd Azam Mohd Amin, "The Development of the concept of Mahdism in the Malay Sunni World," Journal of Islam in Asia (2007), 4 (1): 123-144

[42] Wan Mohd Azam Mohd Amin, Ajaran Sesat. Kuala Lumpur: IIUM Press, 2001. 
[43] Wan Zahidi bin Wan Teh \& Mahmood Sa'ad Nasih, Mengenal Hakikat Syiah,.Kuala Lumpur: Pejabat Mufti Wilayah Persekutuan, 2013.

[44] Wan Zailan Kamaruddin bin Wan Ali \& Ahmad Zuhdi Bin Ismail, "Masyarakat Islam di Negara Brunei Darussalam: Kajian Mengenai Isu dan Cabaran dalam Pemikiran Islam di Era Globalisasi (Muslim Society in Negara Brunei Darussalam: A Study on Issues and Challenges in Islamic Thought in the Era of

Globalisation),” Borneo Research Journal (2009), 3: 187-208

[45] Wan Zailan Kamarudin bin Wan Ali, “Aliran Syi’ah di Nusantara: Perkembangan, Pengaruh dan Kesan,” Jurnal Jabatan Sejarah Universiti Malaya (1994/95)

[46] Watt, W.M. Islamic Philosophy and Theology. Edinburgh: Edinburgh University Press, 1987.

[47] Wollaston, Arthur N., The Sunnis and Shias. Whitefish, Montana: Kessinger Publishing, 2005.

[48] Zulkifli, The Struggle of the Shi' is in Indonesia, Doctoral thesis, Department of Islamic Studies, Faculty of

Humanities, Leiden University.Leiden: Leiden 2009.

https://openaccess.leidenuniv.nl/handle/1887/14017 